\title{
DEVELOPMENT OF STREET VENDOR BUSINESS THROUGH MARKETING COMMUNICATION CAPABILITY IMPROVEMENT IN MENTENG VILLAGE, SOUTH JAKARTA
}

\author{
Theodore Titi Widaningsih ${ }^{1 *}$, Daesy Ekayanti ${ }^{2}$, Nandang Mulyasantosa ${ }^{2}$ \\ ${ }^{1}$ Commucication Science Study Program, Graduate School, Sahid University - Jakarta \\ ${ }^{2}$ Faculty of Communication Science, Sahid University - Jakarta \\ *titi_widaningsih@usahid.ac.id
}

\begin{abstract}
Street vendors make a major contribution to economic activity and public welfare, especially to the weak economic group. Businesses carried out by street vendors are independent and involve the needs of many people. Street vendors as informal sectors have great potential to improve the economy, especially the weak economic community. The potential business of the street vendor at RW 14, RT 139 Menteng Dalam Village, South Jakarta must be developed because all this time they sell only to survive without any business development efforts. The business development can be done through marketing communication skills improvement by providing training. Improved marketing communication skills are carried out so that street vendors can make distinctive products, which are different from other products, always maintain cleanliness and tidiness of the place of business. In determining the selling price not only considering the raw materials that are used but also the costs of labor, electricity and other costs. Conduct simple promotions such as giving a name to the stall, making leaflets, and serving buyers in a friendly and polite manner. Make comparisons with other similar products to make and determine the product prices.
\end{abstract}

Keywords: business development, capabilities, marketing communications, street vendors.

\section{INTRODUCTION}

National development is an effort to improve the quality of human and Indonesian society which is carried out in a sustainable manner, based on national capabilities, by utilizing the advancement of science and technology and must be able to pay attention to the challenges of global development. Micro, Small and Medium Enterprises are an important part of development planning. Micro, Small and Medium Enterprises (MSMEs) are a community-based economic activity with minimal capital. Under UU No.20/2008 about UMKM states that the characteristics of MSMEs are (1) producing consumer goods, especially those that are not durable (non-durable consumer goods), (2) relying on non-banking financing in the aspect of business funding, and (3) conducting strict specialization by producing certain goods or services. (4) not dependent on external factors.

Included in the small and medium micro business sector are street vendors. Street vendors are those who work by utilizing situations, places and crowds or other public places. Based on PermenDalamNegeriNo.41/2012 that street vendors is one way to meet the needs of life amidst limited employment opportunities for those with low education with limited skills. Street vendors have a big role to play in improving the economy of the weak economic community. The growth of street vendors from time to time is very fast in number, by utilizing places that are considered profitable for example city centers, town squares, crowded places and places that have the potential to become tourist attractions. Where the place is considered easier to get consumers. Street vendors thinks that what they do is to make a living. The benefit of the presence of street vendors that is felt by middle to lower class economy people is that they can obtain goods at affordable prices.

Street vendors are potential assets if they are coached, organized and their businesses are developed. Even the Ministry of Labor has set that street vendors are to be coached, regulated and not to be cut off because street vendors play a role in building jobs. Coaching needs to be done because a lot of street vendors do not have sufficient skills due to heredity (Zuliarni, 2013). Small business actors 
usually inherit previous family businesses with a low educational background. Menteng Dalam Village, Tebet Subdistrict, South Jakarta is an area with densely populated settlements. This region has office buildings, campuses, hotels and street vendors growing along with the increase in various activities such as education and works in Menteng Dalam. The presence of street vendors is certainly to meet the needs of consumers such as food stalls, photocopies, groceries, and beverages.

Based on observations made on the street vendors in Menteng Dalam, South Jakarta street vendors has not carried out marketing communications properly. Street vendors makes food products as ready and edible as possible, with inconsistent tastes, the display of the food and packaging is less attractive. Are not trying to make a unique product that could be the trademark of its merchandise. The place to sell is dirty and not comfortable for consumers. The stalls are not named, as identifiers of their existence. Service is done poorly and slowly. Not doing promotions and do not calculate production costs other than raw materials. In order for Menteng village street vendors to develop, it is necessary to coach them. Coaching is done through training and mentoring to improve the ability to conduct marketing communications.

\section{METHOD}

\section{Time and Location}

Community service activities are carried out in October 2016 - June 2017. The location of the activities is in accordance with the location of the partner group, Menteng Dalam Village, South Jakarta. Consisting of $139 \mathrm{RT}$ and $14 \mathrm{RW}$, with an area of 211 ha. There are various office buildings, restaurants, banks, campuses, schools, minimarkets, hotels and street vendors.

\section{Tools and Materials}

The equipment used in this activity is a computer, to provide examples of making logos, brands. LCD, monitor screen, props, paper and stationery.

\section{Activity Implementation Method}

Community service implementation to partners is based on situational analysis and problems found in the partner. Based on the agreement between the team and partners to get the solution to the problem, marketing communication training is carried out which includes several approach methods, that is 1) product development, 2) Structuring and developing the business places, 3) Product pricing, 4) Promotion techniques, and (5) customer service.

\section{RESULT AND DISCUSSION}

\section{Product Development Training}

Marketing communication is directed towards achieving one or more goals. According to Shimp (2003), the objectives of marketing communication are generating desire for product categories, creating brand awareness, encouraging positive attitudes and influencing buying interest, facilitating purchases.

According to Kotler and Armstrong (2005), products are: anything that can be offered to a market for attention acquisition, use or consumption that might satisfy a want or need. The product is anything that can be offered to a market to meet the needs or desires. Products can be in the form of physical goods, services, people, places, creative ideas, organizations and others. Products are created to meet the needs and desires of consumers.

Training on street vendors is carried out by implementing product strategies in the form of product diversity, product quality, design, features, brand names, sales packaging. To raise the desire for products, street vendors need to make unique products that are liked by consumers. Through discussion and assistance, street vendors find several typical menus that can be used as main products such as Nasi Uduk Semur Jengkol, nasi goreng petai, kopi jahe merah, kopi gula merah, nasi gudeg ayam suwir. Make the taste of the product consistent by using standards in production. Packagingthe products well and attractively.an example for wrapping rice does not use paper which easily torn anymore when in contact with liquids or with a used newspaper but uses plastic boxes or stereo forms. For drinks do not use plastic, but can use plastic cups with a lid. 


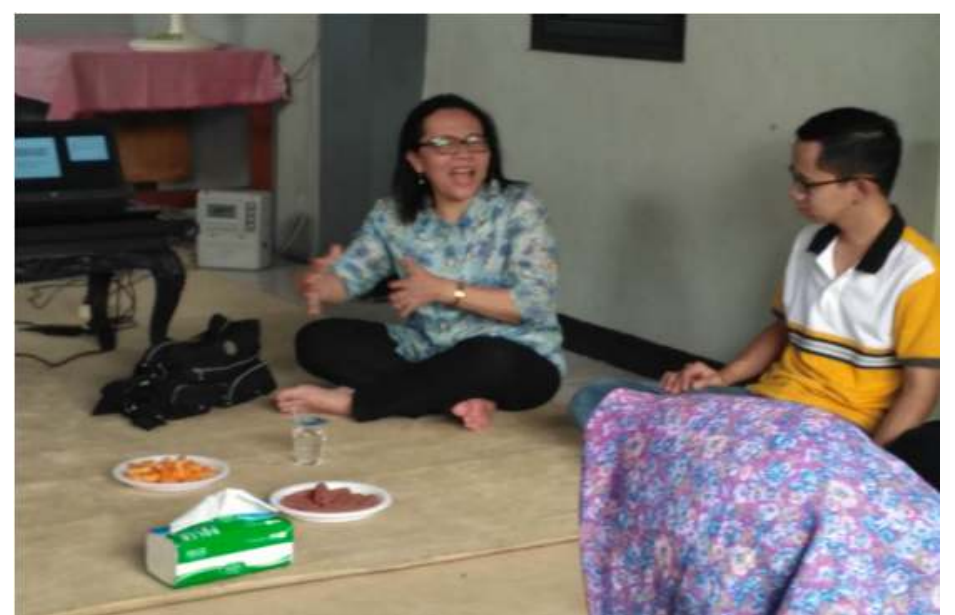

Figure 1. Discussion of street vendor issues with the chairman of the Citizen Association.

Street vendors begins to realize that both goods and services are used to satisfy consumer needs. Product is an important factor and is a central point in marketing. All marketing activities are used to support product marketing. It does not matter how great the promotion, distribution and good prices, if it is not followed by a good quality product and liked by consumers, then the marketing strategy will be in vain and will not succeed.

\section{Business place development training}

Place of business is a place used in distributing goods or services to consumers. Business places in the form of stalls, shops, carts, tents are consumer access to products sold. Marketer activity to distribute products to its target market. The place or product distribution channel becomes important to ensure that target consumers can obtain goods and services in an easy way (Kotler, 2002).Through training Street vendors begin to understand and implement a "place" marketing strategy. Street vendors sells at the right place and time where consumers need it. For example, they open one hour before office hours open and close two hours after the office closes.

Street vendors understands that a name is a brand and this is important how consumers know the product. In creating a brand, it must be creative, creating a name that is easy to recognize and easy to say, with a typical product categorization technique. Through accompaniment street vendors gave a name to his business, for example Nasi Gudeg Mpok Iroh, Nasi Rames Toing, Uda Nasi Padang. Street vendors also begins to maintain the cleanliness and tidiness of places to sell so that consumers are comfortable when visiting. Installing technology devices such as music players, installing fans to cool the room.Arranging the room with adequate lighting. 


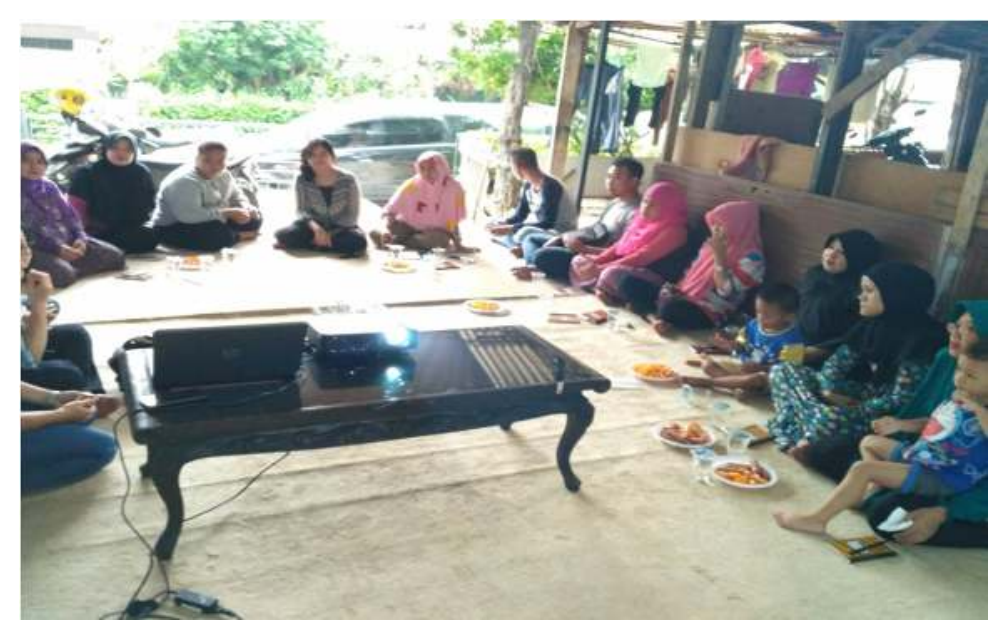

Figure 2.Discussion with street vendors for product development and business places.

\section{Product pricing training}

According to Kotler and Armstrong(2005), prices are the amount of money that customers must pay to get a product. Price is an important component in marketing strategy. The price of a product must be affordable for the product target market. Marketing strategies related to prices include discounts, allowances, payment terms, credit and so on. The product price is determined based on the cost of raw materials, production costs and the desired profit. Raw materials include goods that will be directly sold to consumers and materials that will be processed into products such as food or drinks. Production costs include wages for labor, the cost of fuel such as electricity, gas or kerosene. Providing facilities to consumers such as $\mathrm{Wi}-\mathrm{Fi}, \mathrm{TV}$, fan or AC. After all costs incurred are calculated, the unit price of the product can be determined. The selling price is determined by the unit price of the product added with the amount of profit taken.

Street vendors in Menteng village in South Jakarta has determined the selling price only by calculating the cost of raw materials and profits. The calculated production costs are only fuels that are directly used in production processes such as gas and oil. Labor costs have never been calculated because it is done alone. The Street vendors principle is to return the capital or the cost of basic commodities back and not losing. Street vendors is afraid that selling prices will be expensive if they include labor costs or other production costs that cause street vendors to not be able to compete with other traders, their products are not sold and lost.Through training, street vendors begin to take into account production costs and profits to determine the selling price. Street vendors is very careful in pricing, because errors in setting prices will affect sales. If the price set is too expensive it can cause a decrease in income because customers will look for cheaper products. If the price is too low, then the production costs will not be covered, the income received is small, causing losses. Street vendors starts to realize that prices play a role in determining the success of product marketing. The principle is that a business deserves a profit, so the selling price that is set must be greater than the production costs incurred, so that there is still a difference called profit, some profit must be set aside for investment. Price does not mean cheap or expensive, but the right price.

\section{Promotional techniques training}

Promotion as an activity carried out by the company to communicate the benefits of its products and to convince consumers to buy(Kotler, 2002). Promotion as one of the variables in the marketing mix that is very important is carried out by the company in marketing products and services (Lupiyoadi, 2013). Promotion as a series of techniques used to achieve sales or marketing goals with the use of cost effectiveness, by providing added value to products or services to intermediaries and direct users, is usually not limited to a certain period (Cummins,2010). Through training street vendors understand that promotion is an activity of communicating product excellence so that customers can understand the product and be persuaded to buy. Promotion is important in conveying product information and creating product images for consumers. A good promotion must be able to persuade customers to buy company 
products. Promotion not only serves as a communication tool but as a tool to influence consumers in purchasing activities according to their wants and needs.

Street vendors also began to realize that promotions can be carried out by Street vendors in a simple way. A good promotion will result in product recognition that can increase sales.Through accompaniment Street vendors began to promote by offering products to the offices and campuses that are close to the business location. Make flyers by printing or photocopying. This promotion is done as part of the method of picking up the ball, not just waiting for customers to come to the shop. Some street vendors with limited funds optimize promotion by collaborating with other entrepreneurs. By sending product offerings to consumers, giving certain price discounts / purchase bonuses. Examples for food vendors give free plain tea or water, giving a bonus of one piece of fried tofu / tempe. Introducing products and businesses through free media by creating free web accounts, facebook, twitter.

\section{Customer service training}

Services is all forms of intangible human activities that can meet the needs and desires of others to satisfy each other through exchanges simultaneously. Services is intangible, heterogeneous, produced and consumed simultaneously and cannot be stored or cannot rot. (Norman, 1991).

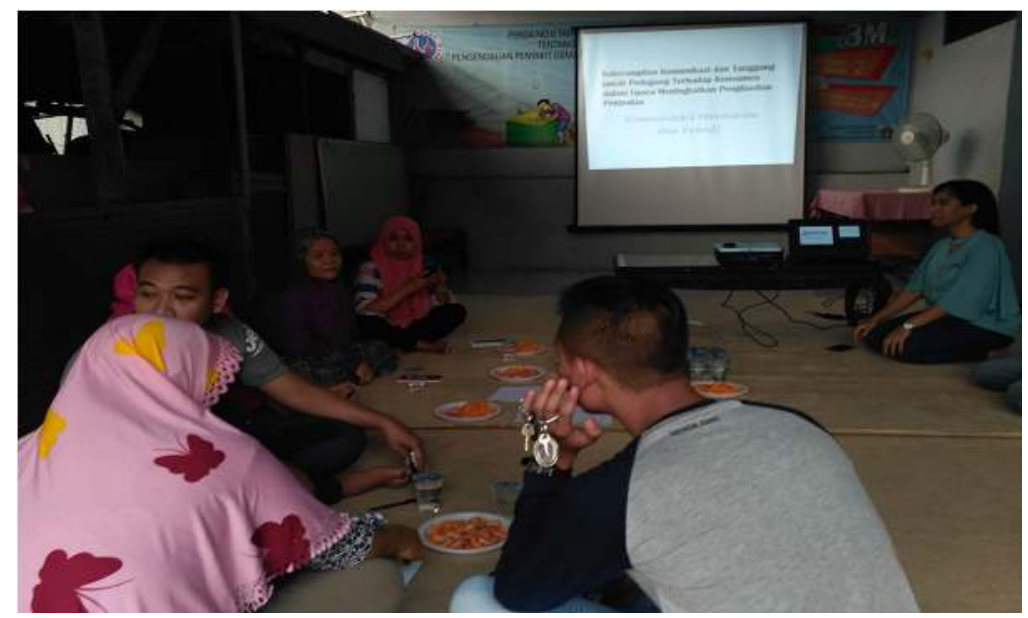

Figure 3.Training on promotion and customer service techniques.

Management of services focuses on managing people. Managing people means managing 3 (three) main domains in people, that is cognitive, affective and conative domains. The cognitive domain is related to knowledge, affective is related to feelings or emotion that is controlled by the "heart" and the conative domain related to behavior, as a form of service produced. Services must be understood as a form of interaction between service providers and service users (consumers or customers). In service management the emphasis is more on how service providers manage services to be delivered to consumers / customers. Customer service is carried out with the aim of providing customer satisfaction.

Customers are expected to be given services quickly and accurately, friendly, polite, safe, service must be in accordance with the information conveyed. Supporting services such as equipment, facilities and infrastructure, physical support must be increased. Service is a process to convey the value of services to customers. Value of services is a comparison between the benefits received by customers compared to the sacrifice or price that has been paid by customers to obtain good service from service providers. Through training Street vendors in Menteng village understands the importance of building good communication with customers. Street vendors began to apply the concept of simple services such as smile and greetings which is a form of friendliness and politeness towards customers. Street vendors tries to avoid errors in service such as inaccuracy, example; food received by consumers does not match the order. Does not make consumers wait too long for food ordered. Services support have also been improved such as cleanliness and comfort by providing trash cans, washbowl/washbasin, tissues, napkins and installing fans. Street vendors can accept, respond and resolve consumer criticism well. Settlement is done by feeling customer disappointment, acknowledging if there is an error, and 
apologizing for the situation. The establishment of good relations between producers and consumers due to the influence of services. Consumer satisfaction with services can make consumers as loyal customers.

\section{CONCLUSION}

The community empowerment program was conducted in the form of training and mentoring in improving the marketing communication skills of street vendors in Menteng Dalam village, South Jakarta. The development of marketing communication skills is carried out by helping to improve the quality of street vendors product. Helping street vendors find unique products that are used as a main product in selling at affordable prices. Helping to make a name / logo as a product identifier and place of business. Improve comfort and cleanliness of the place to sell by providing cleaning equipment. Develop the ability to calculate production costs and determine unit price, calculate profits and encourage street vendors to save / invest. Help conduct promotions by making flyers and informing the product to the public and students. Improve communication skills with customers.

\section{REFERENCES}

Cummins, J. (1991). Promosi penjualan. Jakarta: Binarupa Aksara.

Kotler, P., \& Armstrong, G. (2008).Prinsip-prinsip Pemasaran (judul asli: Principles of Marketing), edisi kedua belas, jilid 1. Penerjemah Bob Sabran. Jakarta: Erlangga.

Kotler, P. (2002). Manajemen Pemasaran Edisi Milenium. Jakarta: PT. Prenhallindo.

Lupiyoadi, R. 2013. Manajemen Pemasaran Jasa. Jakarta: Salemba Empat.

Normann, R. (1991). Service management: strategy and leadership in service business. Wiley.

Peraturan Menteri Dalam Negeri Republik Indonesia Nomor 41 Tahun 2012 Bab I Pasal 1 poin 1.

Shimp, T. A. (2003). Periklanan Promosi Aspek Tambahan Komunikasi Pemasaran Terpadu. Jakarta: Erlangga.

UU no.20 tahun 2001 tentang Usaha Mikro, Kecil dan Menengah.

Zuliarni, S., \& Hidayat, R. T. (2013).Analisis Faktor Pertimbangan Pebisnis Restoran Kelas Kecil Di Lingkungan Kampus Universitas Riau Dalam Pemilihan Lokasi Usaha. Jurnal Aplikasi Bisnis, $3(2), 100-119$. 